\title{
FAKTOR -FAKTOR YANG MEMPENGARUHI INDEKS PRESTASI DOSEN DENGAN SEM-PLS (STUDI KASUS JURUSAN PENDIDIKAN MATEMATIKA DAN TEKNIK ELEKTRO PTS DI SURABAYA)
}

\author{
Susilo Hadi 1), Iva Mamlu'atul Hidayati 2). \\ ${ }^{1}$ Fakultas Keguran dan Ilmu Pendidikan, Universitas PGRI Adi Buana Surabaya \\ email: susilohadi45@gmail.com \\ ${ }^{2}$ Fakultas Teknik, Universitas PGRI Adi Buana Surabaya
}

\begin{abstract}
Abstrak
Unsur dari kompetensi pedagogik merupakan akibat langsung dari kompetensi unsur yang ada dalam kompetensi profesional, selain itu unsur dalam kompetensi sosial be rkaitan erat dengan kompetensi kepribadian. Penelitian ini bertujuan untuk menganalisis pengaruh kompetensi profesional, sosial dan kepribadian terhadap kompetensi pedagogik berdasarkan persepsi mahasiswa. Variabel dependent pada penelitian ini adalah kompetensi pedagogik dan variabel independentnya adalah kompentensi sosial, kompetensi kepribadian dan kompetensi professional. Populasi penelitian ini adalah seluruh mahasiswa program studi pendidikan matematik a dan fakultas teknik Universitas PGRI Adi Buana Surabaya, sampel berjumlah 100 orang yang diambil secara acak. Data dikumpulkan dengan kuisioner. Alat analisis yang digunakan adalah SEM-PLS. Hasil penelitian menunjukkan kompetensi kepribadian, kompetensi profesional dan sosial berpengaruh terhadap kompetensi pedagogik.
\end{abstract}

Keywords: SEM-PLS, Pedagogik, Profesional, Sosial dan Kepribadian

\begin{abstract}
The element of a pedagogic competence is a direct result of the element competence professional competence, on the other hand, the element of social competence is closely associated with personality competence. This study is to analyze the influence of professional competence, societal and personalities to pedagogical competence based on student perception. The dependent variable of this study is the pedagogic competence and the independent variable is a social competence, personality competence and professional competence. The population of this study is all of the Mathemathics Education and Engineering students in UNIV PGRI ADI BUANA SURABAYA, a sample of 100 people is taken randomly. Data is collected by giving questionnaires. The tool of analysis is using SEM-PLS. The results of this study are showing personality competence, professional competence and social competence influenced to pedagogic competence.
\end{abstract}

Keywords: SEM-PLS, Pedagogic, Professional, Social and Personality

\section{PENDAHULUAN}

Pendidikan yang bermutu sangat tergantung pada kapasitas satuan-satuan pendidikan dalam mentranformasikan peserta didik untuk memperoleh nilai tambah,baik yang terkait dengan aspek olah pikir, rasa, hati, dan raganya. Dari sekian banyak komponen pendidikan, guru dan dosen merupakan faktor yang sangat penting dan strategis dalam usaha meningkatkan mutu pendidikan disetiap satuan pendidikan. UU RI No. 14 tahun 2005 tentang Guru dan Dosen yang menyatakan bahwa seorang pendidik perlu memiliki kompetensi pedagogik, kompetensi profesional kompetensi kepribadian dan kompetensi sosial Melalui dimensi-dimensi tersebut dapat dilakukan suatu penilaian yang dapat digunakan untuk meningkatkan kompetensi dalam mendukung kinerja pada kegiatan proses belajar mengajar. Dengan demikian, patut diperhatikan dengan seksama bahwa kompetensi dosen akan sangat 
mempengaruhi kualitas dan kompetensi lulusan perguruan tinggi Kompetensi pedagogik dirinci menjadi kemampuan (a) memahami peserta didik, (b) kemampuan merencanakan, melaksanakan, dan menilai pembelajaran, dan (c) kemampuan mengembangkan peserta didik. Kompetensi kepribadian dirinci menjadi berpribadi mantap dan stabil, arif, berwibawa, dan akhlak mulia. Kemudian kompetensi profesional dirinci menjadi menguasai keilmuan bidang studi dan kajian kritis pendalaman isi bidang studi. Selanjutnya kompetensi sosial dirinci menjadi kemampuan berkomunikasi dengan peserta didik, kolega, dan masyarakat.

Berdasarkan tinjauan diatas maka dapat diketahui bahwa beberapa unsur dari kompetensi pedagogik merupakan akibat langsung dari kompetensi unsur yang ada dalam kompetensi profesional, selain itu unsur dalam kompetensi sosial berkaitan erat dengan kompetensi kepribadian. Hal itu juga diperkuat dari hasil penelitian yang telah dilakukan oleh Suhendar, dengan penelitiannya yang berjudul 'Pengaruh budaya belajar organisasi, dukungan manajemen, daya dukung sarana, dan kualitas pemanfaatan internet terhadap kompetensi guru". Dalam penelitiannya diketahui adanya hubungan antara kompetensi profesional terhadap kompetensi pedagogik, dan hubungan antara kompetensi kepribadian terhadap kompetensi sosial. Sehingga dapat diketahui pada kisi-kisi variabel manifest untuk varibael laten endogen yang diambil secara langsung dari Kepmendiknas nomor 16 tahun 2007 tentang Standar Akademik dan Kompetensi Guru maka dapat diketahui bahwa beberapa unsur dari kompetensi pedagogik merupakan akibat langsung dari kompetensi unsur yang ada dalam kompetensi profesional, selain itu unsur dalam kompetensi sosial berkaitan erat kompetensi kepribadian.

Dalam penelitian ini digunakan metode Structural Equation Modeling Partial Least Square (SEM-PLS), dengan hipotesa yang dibangun adalah sebagai berikut, (1) semakin tinggi tingkat kompetensi profesional yang dimiliki oleh dosen semakin tinggi kompetensi mengajarnya (pedagogik), (2) semakin tinggi kompetensi kepribadian (personaliti), samakin tinggi kompetensi mengajarnya (pedagogik), (3) semakin tinggi kompetensi sosial dosen, semakin tinggi kompetensi mengajarnya (pedagogik).

\section{KAJIAN LITERATUR}

\section{Pengertian Kompe tensi}

Kompetensi merupakan istilah kunci dalam penelitian ini. Kata "kompetensi" berasal dari bahasa Inggris competence, yang berarti kemampuan, keahlian, wewenang dan kekuasaan. Hari Suderadjat (2014: 25) memberikan rambu-rambu tentang makna kompetensi. Secara umum, kompetensi diartikan sebagai pemilikan pengetahuan (konsep dasar keilmuan), keterampilan yang di- butuhkan dalam menyelesaikan suatu pekerjaan di lapangan, dan nilai-nilai serta sikap. Dengan demikian, kompetensi memiliki tiga dimensi yaitu: (1) penguasaan konsep, (2) kecakapan mengimplementasikan konsep, dan (3) pemilikan nilai dan sikap dari konsep yang dikuasai dan diimplementasikannya. Kompetensi juga diartikan sebagai suatu uraian ketrampilan, pengetahuan dan sikap yang utama diperlukan untuk mencapai kinerja yang efektif dalam pekerjaan (Baso, 2013). Dari pihak pemerintah melalui UU RI No. 14 tahun 2005 tentang Guru dan Dosen Bab I pasal 1 ayat 10 mengartikan kompetensi sebagai seperangkat pengetahuan, keterampilan, dan perilaku yang harus dimiliki, dihayati, dan dikuasai oleh guru atau dosen dalam melaksanakan tugas keprofesionalan.

\section{Karakte ris tik Kompetensi Guru/Dosen}

Kompetensi profesional guru atau dosen dapat dikelompokkan menjadi tiga bidang yaitu pedagogik, personal dan sosial Kompetensi pedagogik menyangkut kemampuan intelektual seperti penguasaan mata pelajaran, pengetahuan menganai cara 
mengajar, pengetahuan mengenai belajar dan tingkah laku individu, pegetahuan tentang bimbingan penyuluhan, pengetahuan tentang administrasi kelas, pengetahuan tentang cara menilai hasil belajar, pengetahuan tentang kemasyarakatan serta pengetahuan umum lainnya. Kompetensi bidang personal menyangkut kesiapan dan kesediaan guru/dosen terhadap berbagai hal yang berkenaan dengan tugas dan profesinya. Misalnya sikap menghargai pekerjaannya, mencintai dan memiliki perasaan senang terhadap mata pelajaran yang dibinanya, sikap toleransi terhadap sesama teman profesinya, memiliki kemauan yang keras untuk meningkatkan hasil pekerjaannya. Kompetensi sosial menyangkut kemampuan guru dalam berbagai ketrampilan / berperilaku, seperti ketrampilan mengajar, membimbing, menilai, menggu-nakan alat bantu pengajaran, bergaul atau berkomunikasi dengan siswa, ketram-pilan menumbuhkan semangat belajar para siswa, ketrampilan menyusun persiapan/perencanaan mengajar, ketrampilan me-laksanakan administrasi kelas, dan hin-lain. Kepmendiknas nomor 16 tahun 2007 tentang Standar Akademik dan Kompetensi Guru juga menyebutkan bahwa beberapa unsur dari kompetensi pedagogik merupakan akibat langsung dari kompetensi unsur yang ada dalam kompetensi profesional, selain itu unsur dalam kompetensi sosial berkaitan erat dengan kompetensi kepribadian.

\section{SEM - Partial Least Square (PLS)}

Partial Least Square (PLS) pertama kali dikembangkan oleh Herman Wold sekitar tahun 1966. Pada awalnya PLS dikembangkan sebagai metode umum untuk mengestimasi path mode yang menggunakan variabel laten dengan multiple indocator. PLS awalnya diberi nama NIPALS (Nonlinear Iterative Partial Least Square) karena PLS menggunakan dua prosedur iterative yaitu metode estimasi least squares (LS) untuk single dan multi component model untuk conanical correlation. Pendekatan
PLS adalah distribution free yang artinya data tidak bersyaratkan berdistribusi tertentu, dapat berupa nominal, kategori, ordinal interval dan rasio. Dalam pengembangannya, model dasar PLS diselesaikan oleh Herman Wold pada tahun 1977 yang kemudian dikembangkan lebih lajut oleh Lohmoller pada tahun 1984 dan 1989, dan kemudian dikembangkan okh Chin pada tahun 1996.

PLS merupakan tehnik yang kuat dalam menganalisis variabel laten yang memiliki beberapa indikator pada SEM. Chin PLS menggunakan prosedur estimasi berbasis minimum squares, dimana tidak memiliki tekanan pada skala pengukuran, distribusi data ataupun ukuran sampel Dapat disimpulkan bahwa PLS adalah sebuah pendekatan alternatif yang bergeser dari pendekatan SEM berbasis covariance menjadi berbasis variance. Desain PLS dimaksudkan untuk mengatasi keterbatasan metode SEM lainnya ketika data mengalami masalah seperti pengukuran data dengan skala tertentu, jumlah sampel yang kecil, adanya missing value, data tidak normal dan adanya multikolinearitas. Selain itu PLS dapat digunakan pada setiap jenis skala data (nominal, ordinal, interval, rasio) serta syarat asumsi yang lebih fleksibel.

Terdapat tiga kategori dalam melakukan estimasi parameter pada PLS, yaitu weight estimate, path estimate, dan means dan lokasi parameter. Weight estimate digunakan untuk mencipatakan skor dari variabel laten. Path estimate (estimasi jalur) digunakan untuk menghubungkan antar variabel laten dan juga menghubungkan variabel laten dengan blok indikatornya (loading). Means dan lokasi parameter sebagai nilai konstanta regresi dari indikator dan variabel lain. Selain itu, PLS menggunakan proses iterasi tiga tahap dan estiap tahap menghasilkan estimasi. Tahap pertama menghasilkan weight estimate, tahap kedua menghasilkan inner model dan outer model, dan tahap ketiga menghasilkan means dan lokasi (konstanta). 
Pada tahap pertama dan kedua, komponen skor estimasi untuk setiap variabel laten dapat menggunakan dua cara, yaitu melalui outside approximation dan menggunakan inside approximation. Outside approximation menggambarkan weighted agregat dari indikator konstruk, sedangkan inside aproksimasi menggunakan weighted agregat component score hin yang berhubungan dengan konstruk dalam model teoritis. Pada tahap ketiga, dilakukan perhitungan mean setiap indikator dengan menggunakan data asli untuk mendapatkan parameter mean, kemudian melakukan perhitungan means dari nilai weight pada variabel laten yang didapat dari tahap satu. Dengan nilai mean untuk setiap variabel laten dan path estimate dari tahap dua, maka lokasi parameter untuk setiap variabel laten dependen dihitung sebagai perbedaan antara mean yang baru dihitung dengan systematic part accounted oleh variabel laten yang mempengaruhinya.

\section{METODE PENELITIAN}

\section{Jenis Penelitian}

Penelitian ini merupakan jenis penelitian eksploratif yaitu membuat model indeks prestasi dosen PTS Surabaya yaitu pemodelan struktural kompetensi kepribadian, kompetensi sosial, kompetensi profesional dan kompentensi pedagogik. Sehingga kita dapat mengetahui pola hubungan ke empat variabel laten tersebut sehingga dapat menjadi acuan untuk menentukan Indeks Prestasi Dosen (IPD).

\section{Sumber Data dan Teknik Pengambilan} Data

Jenis data dalam penelitian ini adalah data primer. Teknik pengumpulan dilakukan dengan menggunakan kuesioner dan didukung dengan observasi. populasi dalam penelitian ini adalah mahasiswa perguruan tinggi swasta di Surabaya. Sampel yang di ambil adalah perguruan tinggi swasta yang mempunyai akreditasi minimal B dan mempunyai fakultas ilmu pendidikan dan fakultas teknik. Responden penelitian adalah mahasiswa telah mengambil semester genap pada periode 2017/2018. Sampling probabilitas yang digunakan dalam penelitian ini adalah sampling acak sederhana (simple random sampling). Pada sampling acak sederhana, setiap elemen dari populasi mempunyai peluang sama dan diketahui, untuk terpilih menjadi subjek.

\section{Definisi Operasional dan Pengukuran}

Variabel dalam penelitian ini terdiri dari variabel karakteristik demografi, variabel endogen (kompetensi mengajar/pedagogik), variabel eksogen (kompetensi profesional dan kompetensi sosial) dan variabel moderating (kepribadian/personaliti).

Variabel Karakteristik Responden :

1. Jenis Kelamin

2. Program Pendidikan

3. Tahun Angkatan

Variabel endogen (Kompetensi pedagogik) dan variabel eksogen (Kompetensi Profesionalisme, Kompetensi Kepribadian, Kompetensi Sosial.

\section{Teknik Analis is Data}

Langkah - langkah yang dilakukan peneliti dalam analisis untuk mengetahui indeks prestasi dosen dengan SEM-PLS. Tahapan - tahapan analisis yang digunakan antara lain :

Analisis Deskriptif

Pengujian unidimensionalitas setiap variable laten dengan menggunakan Confirmatory Factor Analysis (CFA).

Analisis SEM berbasis varians (SEM-PLS)

a. Pengembangan model ekploratif

b. Mengkonstruksi diagram Path

\section{Pengembangan model ekploratif}

Mengkostruksi diagram path. Berikut adalah konstruksi diagram jalur dari konsep yang sudah dibangun. 


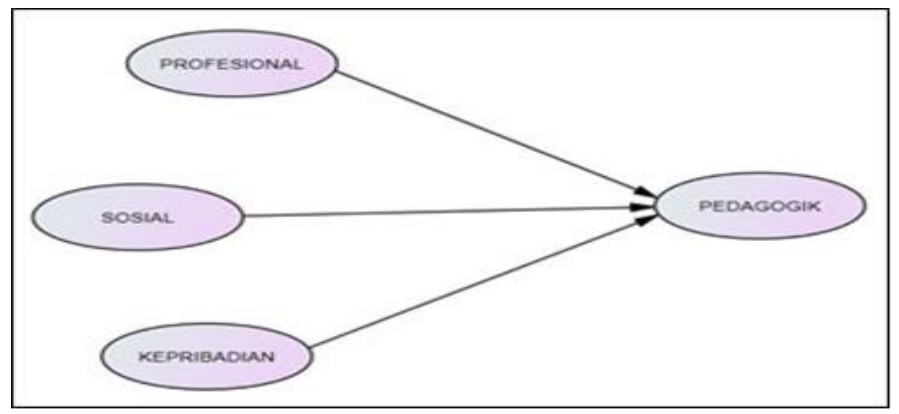

Gambar 3.1 Diagram Jalur (Path Diagram)

\section{HASIL DAN PEMBAHASAN}

\subsection{Gambaran Umum Lokasi Penelitian}

Penelitian ini dilakukan di Universitas

PGRI Adi Buana Surabaya yang memiliki 6 Fakultas dan 21 Program Studi. Populasi penelitian ini adalah seluruh mahasiswa program studi Pendidikan Matematika dan program studi Teknik Elektro. Sampel penelitian ini adalah 50 orang mahasiswa program Studi Pendidikan Matematika dan 50 orang mahasiswa program studi teknik elektro yang diambil secara acak. Pengambilan data diawali dengan kegiatan workshop tentang Penilaian Indeks Prestasi Dosen. Selanjutnya tiap mahasiswa mengisi kuesioner penilaian indeks prestasi dosen terhadap 6 orang dosen yang sudah ditentukan oleh peneliti.

\subsection{Uji Validitas pada Outer Model}

Uji validitas dignakan untuk mengetahui apakah indikator-indikator yang membentuk variabel laten representatif. Dua kriteria yang digunakan untuk menilai validitas dalam outer model yaitu Convergent Validity dan Composite Reliability.

\section{a. Convergent Validity}

Uji validitas dalam model pengukuran (outer model) dilakukan untuk mengetahui validitas indikator dalam membentuk suatu variabel laten (kompetensi pedagogik, professional, kepribadian dan sosial), yaitu dengan mengetahui nilai convergent validity indikator-indikator yang ada di dalam model. Setiap indikator dalam model harus memenuhi convergent validity yaitu memiliki nilai > 0,5 dan signifikan $t$ hitung statistik >1,96. Pengambilan keputusan signifikansi indiaktor dalam merepresentasikan variabel latennya dikatakan signifikan jika nilai $\mathrm{t}$ hitung statistik > 1,96. Hipotesis yang dapat dituliskan dalam uji signifikansi model pengukuran adalah sebagai berikut :

$$
\text { Hipotesis } \mathrm{H}_{0}: \hat{\lambda}_{i}=0
$$

$$
\mathrm{H}_{1}: \hat{\lambda}_{i} \neq 0
$$

Statistik Uji : $\quad t=\frac{\hat{\lambda}_{\hat{i}}}{s e\left(\hat{\lambda}_{i}\right)}$

Daerah penolakan : tolak $\mathrm{H}_{0}$ jika nilai $\mathrm{t}_{\text {hitung }}$ statistic $>1,96$.

Tabel 4.2.1 Uji signifikansi t-statistik

\begin{tabular}{lcccl}
$\begin{array}{c}\text { Hubungan } \\
\text { Variabel laten } \\
\text { dengan } \\
\text { indikator }\end{array}$ & $\begin{array}{c}\text { Sample } \\
\text { Mean (M) }\end{array}$ & $\begin{array}{c}\text { Standard } \\
\text { Error } \\
\text { (STERR) }\end{array}$ & $\begin{array}{c}\text { T Statis tics } \\
(\mid \mathbf{O} / \text { STERR })\end{array}$ & Keterangan \\
\hline KP1 <- KPR & 0.816436 & 0.014045 & 58.125496 & Signifikan \\
KP2 <- KPR & 0.863609 & 0.012681 & 68.122558 & Signifikan \\
KP3 <- KPR & 0.837014 & 0.012436 & 67.370437 & Signifikan \\
KP4 <- KPR & 0.80986 & 0.015232 & 53.223756 & Signifikan \\
KP5 <- KPR & 0.859849 & 0.013439 & 63.995967 & Signifikan \\
KP6 <- KPR & 0.85618 & 0.013637 & 62.756022 & Signifikan \\
PDG1 <- PDGK & 0.754205 & 0.020192 & 37.342917 & Signifikan
\end{tabular}




$\begin{array}{lcccc}\text { PDG2 <- PDGK } & 0.720798 & 0.020688 & 34.900864 & \text { Signifikan } \\ \text { PDG3 <- PDGK } & 0.796949 & 0.016997 & 46.954501 & \text { Signifikan } \\ \text { PDG4 <- PDGK } & 0.788498 & 0.017629 & 44.723154 & \text { Signifikan } \\ \text { PDG5 <- PDGK } & 0.763906 & 0.01895 & 40.404414 & \text { Signifikan } \\ \text { PDG6 <- PDGK } & 0.818919 & 0.016216 & 50.582478 & \text { Signifikan } \\ \text { PDG7 <- PDGK } & 0.795074 & 0.017026 & 46.629786 & \text { Signifikan } \\ \text { PDG8 <- PDGK } & 0.804651 & 0.016243 & 49.555137 & \text { Signifikan } \\ \text { PDG9 <- PDGK } & 0.797711 & 0.016318 & 48.875808 & \text { Signifikan } \\ \text { PROF1 <- PROF } & 0.780563 & 0.018997 & 41.191009 & \text { Signifikan } \\ \text { PROF2 <- PROF } & 0.825148 & 0.016309 & 50.699526 & \text { Signifikan } \\ \text { PROF3 <- PROF } & 0.783373 & 0.017004 & 46.172393 & \text { Signifikan } \\ \text { PROF4 <- PROF } & 0.80414 & 0.01576 & 51.109821 & \text { Signifikan } \\ \text { PROF5 <- PROF } & 0.769304 & 0.021353 & 36.065476 & \text { Signifikan } \\ \text { PROF6 <- PROF } & 0.812445 & 0.016888 & 48.199011 & \text { Signifikan } \\ \text { PROF7 <- PROF } & 0.809284 & 0.015305 & 52.901197 & \text { Signifikan } \\ \text { PROF8 <- PROF } & 0.778988 & 0.020278 & 38.449117 & \text { Signifikan } \\ \text { SOS1 <- SOS } & 0.829376 & 0.016739 & 49.58134 & \text { Signifikan } \\ \text { SOS2 <- SOS } & 0.825446 & 0.016261 & 50.855371 & \text { Signifikan } \\ \text { SOS3 <- SOS } & 0.824908 & 0.014364 & 57.481353 & \text { Signifikan } \\ \text { SOS4 <- SOS } & 0.847207 & 0.013004 & 65.143093 & \text { Signifikan } \\ \text { SOS5 <- SOS } & 0.830419 & 0.015427 & 53.783955 & \text { Signifikan }\end{array}$

Tabel 4.2.1 menunjukkan bahwa estimasi nilai loading pada masing-masing variabel laten adalah signifikan, hal ini ditunjukkan dengan nilai t-statistik yang lebih besar dari 1,96.

\section{b. Uji Reliabilitas (Composite Reliability)}

Composite reliability bertujuan untuk menguji reliabilitas variabel laten atau konstruk. Ukuran reliabilitas menunjukkan nilai yang baik jika >0,7 (Chin, 1998). Hasil nilai composite reliability pada Tabel 4.2.2 menunjukkan bahwa semua blok indikator yang mengukur konstruk kompetensi pedagogik, professional, kepribadian dan sosial $>0,7$. Sehingga variabel laten kompetensi pedagogik, professional, kepribadian dan sosial dikatakan memiliki reliabilitas yang baik.

Tabel 4.2.2 Hasil Uji Reliabilitas (Composite Reliability)

\begin{tabular}{lcc}
\multicolumn{1}{c}{ Variabel Laten } & Composite Reliability & Ke terangan \\
\hline Kepribadian & 0.935451 & Reliabel \\
Pedagogik & 0.934508 & Reliabel \\
Profesional & 0.932943 & Reliabel \\
Sosial & 0.918287 & Reliabel
\end{tabular}

\subsection{Persamaan Model Struktural SEM PLS}

Analisis pada model struktural digunakan untuk mengetahui pengaruh dan signifikansi hubungan antara kompetensi profesional, sosial dan kepribadian terhadap kompetensi pedagogik. 


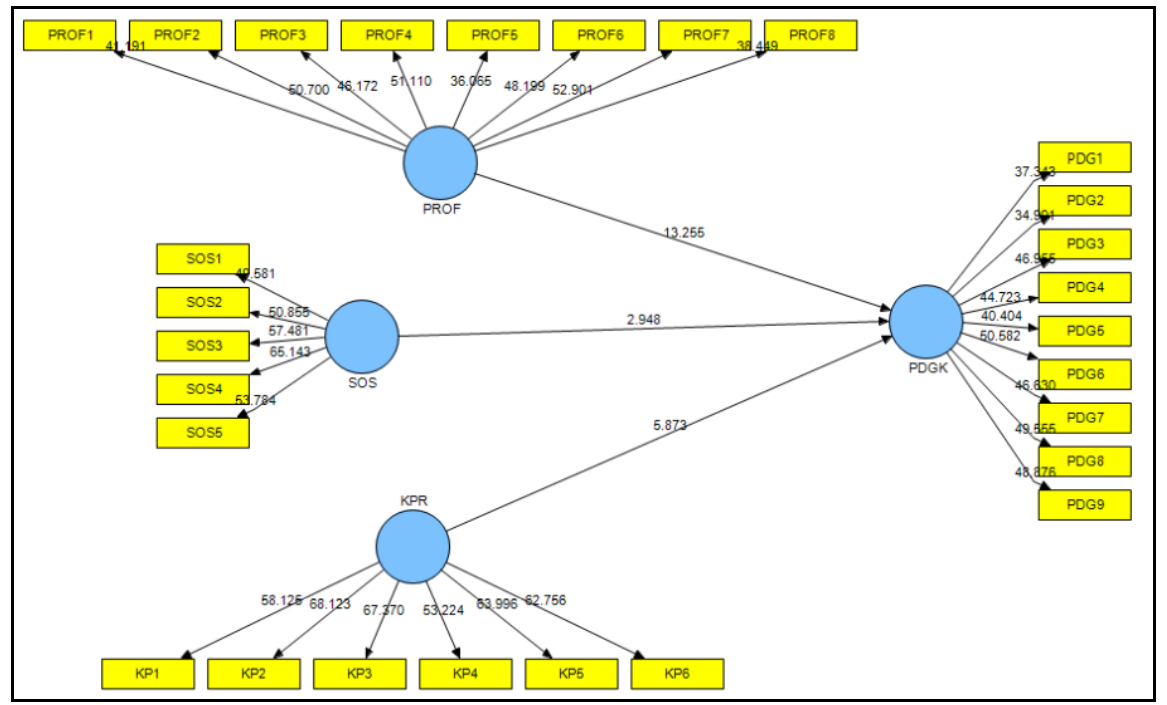

Gambar 4.2 Signifikansi t statistik hubungan antar variabel laten dan indikator

Tabel 4.2.3 berikut menggambarkan estimasi model dan signifikansi pengaruh hubungan antar variabel laten pada persamaan struktural SEM PLS. Pengaruh signifikansi hubungan antar variabel laten dikatakan signifikan apabila nilai $\mathrm{t}$ statistik $>1,96$.

Tabel 4.2.3 Nilai koefisien jalur model struktural dengan sampel bootstrap 250

\begin{tabular}{lcccc}
$\begin{array}{c}\text { Hubungan antar variabel } \\
\text { laten }\end{array}$ & $\begin{array}{c}\text { Original } \\
\text { Sample (O) }\end{array}$ & $\begin{array}{c}\text { Standard } \\
\text { Error } \\
\text { (STERR) }\end{array}$ & $\begin{array}{c}\text { T Statistics } \\
(\mid \mathbf{O} / \text { STERR|) }\end{array}$ & Keterangan \\
\hline Kepribadian -> Pedagogik & 0.273085 & 0.046495 & 5.873381 & Signifikan \\
Profesional -> Pedagogik & 0.535475 & 0.040397 & 13.255389 & Signifikan \\
Sosial -> Pedagogik & 0.147668 & 0.050099 & 2.947524 & Signifikan
\end{tabular}

Berdasarkan hasil pada tabel 5.4.1 dapat diketahui bahwa kompetensi professional, sosial dan kepribadian berpengaruh signifikan terhadap kompetensi pedagogik ( $\mathrm{t}$ statistik >1,96) Model persamaan pada tabel 5.4.1 dapat dituliskan sebagai berikut : Pedagogik $=0,535475$ profesional $+0,147668$ sosial $+0,273085$ kepribadian

Dari persamaan diatas dan hasil signifikansi model dapat dijelaskan bahwa kompetensi professional dosen berpengaruh signifikan terhadap kompetensi pedagogik dengan nilai koefisien jalur sebesar 0,535475. Kompetensi sosial dosen berpengaruh signifikan terhadap kompetensi pedagogik dengan nilai koefisien jalur sebesar 0,147668. Kompetensi kepribadian dosen berpengaruh signifikan terhadap kompetensi pedagogik dengan nilai koefisien jalur sebesar 0,273085. Dan kebaikan yang dapat dijelaskan oleh model / $R$ square adalah sebesar $83,09 \%$.

\section{KESIMPULAN}

Berdasarkan tujuan penelitian yang sudah ditetapkan dan hasil pengolahan data , maka dapat disimpulkan sebagai berikut: (1) Semakin baik kompetensi profesional dosen maka akan semakin baik kompetensi pedagogik, (2) Semakin baik kompetensi sosial dosen maka akan semakin baik 
kompetensi pedagogik, (3) Semakin baik kompetensi kepribadian dosen maka akan semakin baik kompetensi pedagogik.

Saran

Berdasarkan kesimpulan diatas, maka saran yang dapat diberikan adalah sebagai berikut

\section{Kepada lembaga PTS}

Penelitian ini melibatkan mahasiswa sebagai responden, dan hasilnya sangat bermanfaat untuk bahan pembinaan kualitas dosen, sehingga penelitian ini hendaknya bisa ditindaklanjuti dengan memberikan kuisioner secara periodik di tiap akhir semester.

\section{Kepada Peneliti}

Penelitian ini bisa dikembangkan lebih lanjut untuk mengidentifikasi pengaruh variable moderator dengan analisiss M-SEM.

\section{REFERENSI}

Baso, Moerad, H. M.(2013)."Pembinaan SDM Berbasis Kompetensi", USAHAWAN/ No. 02 / Th. XXXII / Februari

Fahruddin.(2007). Quality Assurance dalam Pembelajaran (Analisis FaktorFaktor Kepuasan Mahasiswa terhadap Kompetensi Dosen UIN Sunan Kalijaga Yogyakarta). kasadaranlink.blogspot.com/.../qualityassurance-dalam- pembelajaran.html.

Ghozali, I. (2011). Structural Equation Modeling (Teori, Konsep dan Aplikasi dengan Program Amos 20). Semarang : Badan Penerbit Universitas Diponegoro.

Kreitner dan Kinicki. (2015). Perilaku Organisasi Jakarta Salemba empat.

Peraturan Pemerintah RI Nomor 19 tahun 2005 tentang Standar Nasional Pendidikan Republik Indonesia,

Peraturan Pemerintah (PP) Nomor 16 Tahun 2007 Tentang Standar Kualifikasi Akademik dan Kompetensi Guru.

Suderadjat,H.(2014). Implementasi Kurikulum Berbasis Kompetensi (KBK): Pembaharuan Pendidikan dalam
Undang-undang Sisdiknas 2003, Bandung: CV Cipta Cekas Grafika.. Sugiyono.(2007). Metode Penelitian Administrasi. Bandung Alfabeta.

UU no 14 tahun 2005 Tentang Guru dan

Dosen Republik Indonesia. 